\title{
WOMEN IN MANAGEMENT POSITIONS AND ROLE CONFLICT IN WEST AFRICA MILK COMPANY (WAMCO) OGBA, LAGOS, NIGERIA
}

\author{
Chiemeka, Onyema PhD \\ Department of Sociology \\ Imo State University, Owerri, Imo State, Nigeria
}

\author{
Iwu, Uchenna Okechukwu \\ Department of Sociology \\ Imo State University, Owerri, Imo State, Nigeria
}

\begin{abstract}
This work investigated the effects of women in management position on role conflict in WAMCO. Women's participation in the labour force has contributed immensely to the development of the society but they tend to leave their responsibilities as home managers to other people due to the tedious requirement as top managers in various organizations, which could be likened to what women in West Africa Milk Company Plc are currently facing. The objective of this research examined whether the hours spent at work by women in managerial positions affects their marital obligations of child care. The researcher formulated one hypothesis which states that: there is a significant relationship between the hours spent at work by women in managerial positions and marital obligations of child care.328 set of questionnaire were distributed while the researcher retrieved only 326 questionnaire. The questionnaire served as a source of primary data, while library research was source of secondary data. We adopted the survey research design for this study. The purposive sampling technique was adopted. Our hypothesis was tested using the chi-square statistical tool. We found out that women involvement in management positions has contributed greatly in ensuring that they effectively care for their children. This is not in line with Taiwo (2015) that most women who find themselves as managers in organizations tend to have little or no attention for their children. But the it is in line with item 1 in table II as 55.5 percent of the respondents strongly agreed that women's involvement in management positions has enabled them (women) effectively care for their children. Based on the research findings, we recommend that: More women should be granted the opportunity to be involved in managerial positions in their various organizations so that they would be able to care for their children and other family members.
\end{abstract}

Keywords - Management, Positions, Childcare, Women

\section{INTRODUCTION}

The participation of women in the economic sector has been an important feature of the post-independence era. In this modern society, women now agitate for equality with men in their various offices. They keep aspiring for higher positions in different organizations such as banks, ministries, schools etc. thereby compromising their roles as managers of homes.

According to Maher (2011), administrative/ management positions require hard work, long hours which may stress women. For women, this burden is added on their child-care, home and family responsibilities which are referred to as the "double shift". The threat to the concept of exclusive household role for women emerged partly as a result of husband's inability to singularly shoulder the financial responsibility of the family. The boom which education received in the past few years, contributed to opening up tremendous opportunities for women in management positions. Women's participation in the labour force has contributed immensely to the development of the society but they tend to leave their responsibilities as home managers to other people due to the tedious requirement as top managers in various organizations, which could be likened to what women in West Africa Milk Company Plc are currently facing. Most activities around the home resolve around women.

Ugwulebo (2011) argues that most women, due to the nature of their work tend to leave the children and husband in the hands of their maid, that before she comes back from work, the husband may have promoted the maid to the post of a mini-madam or even senior madam. In addition to their parental roles, they perform both domestic and occupational roles for income generation and for the maintenance of their family. The roles of women cannot therefore be undermined in the society. Therefore, women should be special targets for development in order to enhance the efficiency and effective use of human resources. Akande (2013) is of the opinion that the peace and stability at home depends largely on the managerial abilities of women folk. Mothers plan, organize, direct and co-ordinate all the resources for the benefits of all the members of the family.

A woman is therefore responsible for the training of the children in the home to become useful to the family and the nation in the future. She is to cater for the physical, 


\section{International Journal of Engineering Applied Sciences and Technology, 2019 \\ Vol. 4, Issue 8, ISSN No. 2455-2143, Pages 27-32 \\ Published Online December 2019 in IJEAST (http://www.ijeast.com)}

emotional and the spiritual needs of the family. A woman is also in charge of home management and she is expected to use the available resources effectively to cater for the family (Akinfenwa, 2006). Participation of women in the modern sector is based on socially defined roles and duties of women available and committed to caring for the family. While we accept the dominance of the social system in defining social role for the sexes, it was positioned that a large number of women particularly those with education no longer accept the family oriented occupations as fulfilling their needs.

In this view, the effect of management roles/positions on the roles of women as home managers has to be put into considerations because effective management of the home promotes national development but whenever this is lacking, the contrary is usually the case.

This work is therefore, interested in looking at the problems confronting women in management position in the execution of the duties of their offices.

\section{OBJECTIVE OF THE STUDY}

To examine whether the hours spent at work by women in managerial positions affects their marital obligations of child care.

\section{HYPOTHESIS}

There is a significant relationship between the hours spent at work by women in managerial positions and marital obligations of child care.

\section{LITERATURE REVIEW AND THEORETICAL FRAMEWORK}

According to Taiwo (2015) most women who find themselves as managers in organizations tend to have little or no attention for their children. The opinion of some scholars reviewed above indicated that there is a direct influence of women's involvement in paid labour on marital life. Though, considering the various home technology that make home chores easy, child care system, and family flexibilities that exist at work places to enable married women to cope with home obligation, one would wonder whether women involvement in paid labour actually exerts strain on their marital obligation. To ascertain the impact of time women spend at work on their marital obligation of child care, the views of scholars reviewed above did not establish a consensus on the hours women spend at work and the quality of child care. In the next section, discussion will centre on the relationship between the income/earnings of women in paid labour and family authority structure.

Oriaku (2010) asserts that participation of women in employment activities in the modern sector is based on socially defined roles and duties of women available and committed to caring for the family. He further stated that some women, particularly those with education no longer accept the family oriented occupation which is based on caring for the children. Thus, women in management position seems to careless for their children as they see their role in organization as more important than taking care of the home. Ikenna and Uwadi (2016) argues that society views women in management position as trying to abandon their children in the hands of housemaids. Hedges (2012), posits that lack of adequate care for children of the working mothers is not only a serious obstacle to employment of women but it is also a matter of social concern as the welfare of the child is at stake. Even when the helpers, relatives, baby sitters, grannies etc. are present, the attention of the mother is still highly needed. The absence of mothers at home obstructs the adequate care for children. This means that some wrong values can be inculcated into the children by the house help/maid as a result of inadequate care and attention resulting from the involvement of women in paid labour.

As a consequence of the above, working class women or employed women have a shorter time for nursing their children than those who are not employed. Children of employed mothers in paid labour have little time to enjoy or stay with their mothers in the morning before they go to work, later in the evening and throughout the night. It is important to note that child birth and care are of greatest importance to women and child development. Ugwulebo (2001) is also of the view that when women do not care properly for their family, that it will result to conflict in the family which might even bring about disunity among family members. Therefore, traditionally the African woman is supposed to be passive intuitive and down to earth and she is not allowed to work outside the home, because if she does, the family might suffer a lot as the children are the ones to suffer the greatest pain, as such a woman might give in all her time to her job. According to Bhafia (1983:140), the family environment has a direct bearing on women's job performance and consequent job satisfaction. Okoronkwo (2016) contends that female managers are more satisfied with their jobs than taking care of the family. Ross and Peter (1988), are of the view that child care obligation prevents female managers from getting to the zenith of their careers.

Jacobs and Gerson (2001) argue that jobs that require very long hours are not family friendly. Long hours restrict the hours that mothers can spend with their children, which may have an impact on the emotional and intellectual development of a child. They are of the opinion that gender equity is undermined by long hours of work because it is women who are most likely to give up their careers for the sake of their children. Women who remain in paid work are required to make trade-offs between work and the time and energy devoted to domestic labour. In the view of Ezeigbo (2014), woman were consigned to the homes as breeding machines, they were not allowed to choose relatively challenging discipline such as medicine, engineering, politics etc. Thus, in the words of Ugwulebo and Anele (2011), there is a correlation between the acquisition education by women and 


\section{International Journal of Engineering Applied Sciences and Technology, 2019 Vol. 4, Issue 8, ISSN No. 2455-2143, Pages 27-32 \\ Published Online December 2019 in IJEAST (http://www.ijeast.com)}

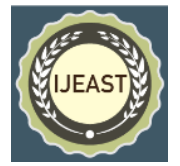

change in their economic roles. The issue of education has played a role in the changing role of women, by making many of them know their right as women and also help them in saying no those formal old traditions and customs. Also, is evident that the relationship between couples and the character of the family life have become more varied and complex than it used to be. Now, the nature of the change in women's occupation and its implication on marital relationship may not only be determined by internal factors, but also by many other external factors. Despite the seeming insistence of men that the place of women in the society is in their homes as wives and mothers, women are increasingly gaining entry into the labour market outside matrimonial homes. This has made many men to feel that women are now taking up professions hitherto monopolized by the men and consequently threatening their patriarchal power. Despite this change in women's occupational status, the society still frowns at women who have climbed high in the social ladder because it is believed that their major occupation is to care for the family. According to Obinna (2016), women play important roles in shaping the adult lives of their children. They invest their time and resources in activities that affect their children's wellbeing. Maduba (2016), contends that in the process of looking for money to care for the children, women tend to forget that their main role as mothers is to constantly monitor their children's development and way of life. He further stated women that only provide money for the child upbringing without proper care for their children may face the problem of trying to keep her family together in the latter days of her life. For him, the major problem in trying to measure the effect of women's employment pattern on longer- term outcomes for their children is that women choose their occupational pattern inconjuction with choices about the way they spend their time and money on children. This emphasizes the need to take account of other factors like children's educational achievements. Elvis (2016), contends that children of women who are employed outside the home performs poorly in terms of academics. He further states that children needs care and affection, which is one of the primary duty of the primary duty of a mother in the home. Benson (2016) argues that motherhood confers upon a woman the responsibility of raising a child. This process also changes the way in which she is perceived in society and at her work place. It can necessitate her to take more available leave options, and job security can be at risk. Significant social and personal adjustments are necessary to cope with such situations. He further states that a working mother especially one who has the good fortune to be available to balance her home and work, enjoys the stimulation that a job or career provides. She develops the ability of raising useful members of society, and at the same time, gains financial independence. Anyaoha and Onyema (2015), contends that when a woman's occupation changes, time to care for her children becomes an issue. According to them, time issue is a critical aspect of paid work and family life. Wives needs enough time at home to take care of the children and at work place they also need to put enough hours so as to achieve the objectives of the organization. In the Nigerian society, it is almost a taboo for a man to help his wife with house chores. He would be ridiculed by friends who would call him names like "woman wrapper" behind his back or even to his face. The average Nigerian man believes that the house chores which include child care obligation is the sole responsibility of the woman. Aguoru (2015), thereby states that significant relationship exists between the changing occupational status of women and child care obligation. For him, women who cannot care for their children at home will also find it difficult to carry out simple task/assignment in their place of work. He also revealed that children who do not have or experience motherly care may have inferiority complex compared to other children that have motherly love and care from their mother.

Above all, women workers are still to learn how to effectively cope with their dual role as preserves of the home and industrial sector workers, because if they fail in their home duties, the children are the ones to suffer the pain.

This study adopted the role theory. This theory is of the view that each social role is a set of rights, duties, expectations, norms and behaviours that a person has to face and fulfill. The model is based on the observation that people behave in a predictable way, and that an individual's behaviour is context specific. Thus, when women starts accepting managerial roles which earns them pay outside the home it will definitely result into role conflict as she would always want to satisfy her employer, and may neglect the home which should be her primary duty. This theory is also of the view that changed conditions can also lead to social and economic pressure, this is likely to lead to role change.

A key insight of this theory is that when role conflict occurs, a woman is expected to simultaneously act out multiple roles that is contradictory in expectations. For instance, most people hold pre-conceived notions of the role expectations of a mother who is a manager outside the home, which her duties might include making sure that the organizations goals are being achieved and at the same time, the family does not suffer. In a situation where one suffers at the expense of others we say role conflict has set in. In other to avoid role conflict, women in managerial positions must learn how to ensure that they maintain a balance between their jobs and their duties as mother at home.

\section{METHODOLOGY}

The research design for this work is the survey research design. Survey research design means the investigation of the opinion, behaviour or other manifestations of a group by questioning them. The researcher adopted the survey research design because of its flexibility to permit the use of a variety of data collection techniques. Also, survey research design sensitizes the researchers to potential problems that were originally unknown. The area of this study is WAMCO Nigeria plc, Ogba, Lagos. Wamco was 
established in 1960. Wamco is situated at ogba in Lagos Nigeria. The company has 920 employees of which women are 435 in number.

Wamco has ten departments which include production, packaging, accounts, research and development, health, operations, sales, marketing, quality assurance and security and safety.

The population of this study is the population of all the women in WAMCO Nigeria plc. which is 435 . The researcher chose 326 as the sample size of the study using the purposive sampling technique. The respondents were drawn from all the 10 departments in WAMCO Nigeria plc.

Table I Departments and their sample size proportion.

\begin{tabular}{|c|c|c|c|}
\hline Item & Departments & $\begin{array}{l}\text { No of } \\
\text { staffs }\end{array}$ & Respondents \\
\hline 1 & Production & 43 & 43 \\
\hline 2 & Marketing & 65 & 65 \\
\hline 3 & $\begin{array}{l}\text { Research and } \\
\text { development }\end{array}$ & 40 & 40 \\
\hline 4 & Sales & 67 & 67 \\
\hline 5 & Packaging & 55 & 68 \\
\hline 6 & $\begin{array}{l}\text { Research and } \\
\text { Development }\end{array}$ & 42 & 42 \\
\hline 7 & Health & 33 & 33 \\
\hline 8 & Operations & 30 & 30 \\
\hline 9 & Quality Assurance & 31 & 31 \\
\hline 10 & Security and Safety & 29 & 29 \\
\hline Total & & 435 & 435 \\
\hline
\end{tabular}

Source; (Human resources department of Wamco)

The researchers adopted the purposive sampling technique because of the nature of the topic under study. The researcher used the questionnaire to gather data for the study, the researcher also used secondary methods such as text books, journals, etc. Data obtained was presented using simple percentages and tables, while the hypothesis was tested using the chi-square $\left(\mathrm{X}^{2}\right)$ statistical tool. This is because it enhances calculation and comprehension. It also gives the opportunity to establish relationship between variables.

$\begin{array}{lll}\frac{\sum(\mathrm{O}-\mathrm{E})}{\mathrm{E}} & \text { Formular for chi-square }(\mathrm{X}) \\ \mathrm{O}= & \text { Observed frequency } \\ \mathrm{E}= & \text { Expected frequency } \\ \sum & = & \text { Summing over the cells. }\end{array}$

\section{RESULT AND DISCUSSION}

Table II Hours Spent at Work by Women in Managerial Positions and Marital Obligations of Child Care

\begin{tabular}{|c|c|c|c|c|c|c|c|}
\hline & Questions & SA & $\mathrm{A}$ & SD & D & $\begin{array}{l}\text { Tot } \\
\text { al } \\
\text { sam } \\
\text { ple }\end{array}$ & $\%$ \\
\hline 1 & $\begin{array}{l}\text { Women who spend } \\
\text { longer time at work } \\
\text { adequately care for } \\
\text { their children? }\end{array}$ & $\begin{array}{l}181 \\
(55.5 \\
\%)\end{array}$ & $\begin{array}{l}101 \\
(31 \\
\%)\end{array}$ & $\begin{array}{l}19 \\
(5.8 \\
\%)\end{array}$ & $\begin{array}{l}25 \\
(7.7 \\
\%)\end{array}$ & 326 & $\begin{array}{l}10 \\
0\end{array}$ \\
\hline 2 & $\begin{array}{l}\text { Women can } \\
\text { combine } \\
\text { managerial position } \\
\text { with childcare } \\
\text { obligations? }\end{array}$ & $\begin{array}{l}171 \\
(52.4 \\
\%)\end{array}$ & $\begin{array}{l}152 \\
(46 . \\
6 \%)\end{array}$ & $\begin{array}{l}15 \\
(4.6 \\
\%)\end{array}$ & $\begin{array}{l}22 \\
(6.7 \\
\%)\end{array}$ & 326 & $\begin{array}{l}10 \\
0\end{array}$ \\
\hline 3 & $\begin{array}{l}\text { Children of women } \\
\text { in management } \\
\text { positions perform } \\
\text { poorly } \\
\text { academically? }\end{array}$ & $\begin{array}{l}20 \\
(6.1 \\
\%)\end{array}$ & $\begin{array}{l}14 \\
(4.3 \\
\%)\end{array}$ & $\begin{array}{l}168 \\
(51 . \\
5 \% \\
)\end{array}$ & $\begin{array}{l}158 \\
(48 . \\
5 \%)\end{array}$ & 326 & $\begin{array}{l}10 \\
0\end{array}$ \\
\hline 4 & $\begin{array}{l}\text { Managerial } \\
\text { positions of women } \\
\text { have caused chaos } \\
\text { in the family } \\
\text { especially among } \\
\text { the children? }\end{array}$ & $\begin{array}{l}7 \\
(2.1 \\
\%)\end{array}$ & $\begin{array}{l}21 \\
(6.4 \\
\%)\end{array}$ & $\begin{array}{l}110 \\
(33 . \\
7 \% \\
)\end{array}$ & $\begin{array}{l}188 \\
(57 . \\
7 \%)\end{array}$ & 326 & $\begin{array}{l}10 \\
0\end{array}$ \\
\hline 5 & $\begin{array}{l}\text { Women } \\
\text { purposefully accept } \\
\text { managerial } \\
\text { positions in their } \\
\text { places of work in } \\
\text { order to effectively } \\
\text { provide for their } \\
\text { children? }\end{array}$ & $\begin{array}{l}111 \\
(34.0 \\
\%)\end{array}$ & $\begin{array}{l}187 \\
(57 . \\
4 \%)\end{array}$ & $\begin{array}{l}25 \\
(7.7 \\
\%)\end{array}$ & $\begin{array}{l}3 \\
(0.9 \\
\%)\end{array}$ & 326 & $\begin{array}{l}10 \\
0\end{array}$ \\
\hline
\end{tabular}

The above table shows that 55.5 percent of the respondents affirmed that women who spend longer time at work adequately care for their children. This could due to the fact that they hire house maids to care for their children. These house maid act like mother to the children and ensure that the children do not go hungry while their real mothers are at work.

Table III Chi-Square Analysis for Hours Spent at Work by Women in Managerial Positions and Marital Obligations of Child Care

\begin{tabular}{|l|l|l|l|l|l|}
\hline Items & SA & A & D & SD & Total \\
\hline 1 & 181 & 101 & 19 & 25 & $326 \mathrm{~B} 1$ \\
\hline 3 & 20 & 14 & 168 & 158 & $326 \mathrm{~B} 2$ \\
\hline 4 & 7 & 21 & 110 & 188 & $326 \mathrm{~B} 3$ \\
\hline Total & $208 \mathrm{~A} 1$ & $136 \mathrm{~A} 2$ & $297 \mathrm{~A} 3$ & $371 \mathrm{~A} 4$ & 978 \\
\hline
\end{tabular}




\section{International Journal of Engineering Applied Sciences and Technology, 2019 \\ Vol. 4, Issue 8, ISSN No. 2455-2143, Pages 27-32 \\ Published Online December 2019 in IJEAST (http://www.ijeast.com)}

Computing formular for chi-square

$\mathrm{X} 2=\frac{\sum\left(\mathrm{O}_{1}-\mathrm{E}_{1}\right)^{2}}{\mathrm{E}_{1}}$

Where $\sum=$ Summation

$$
\begin{aligned}
& \mathrm{O}=\text { Observed values } \\
& \mathrm{E}=\text { Expected values }
\end{aligned}
$$

To obtain the expected frequencies

$\mathrm{E}=\underline{\text { Row total } \mathrm{x} \text { column }}$

$$
\text { Grand total }
$$

Placing the observed and expected values in a tabular form, we have;

Table 4.2.2: $\quad$ Data for hypothesis one

\begin{tabular}{|l|l|l|l|}
\hline $\mathrm{O}$ & $\mathrm{E}$ & $(\mathrm{O}-\mathrm{E})$ & $(\mathrm{O}-\mathrm{E})^{2 / \mathrm{E}}$ \\
\hline 208 & 69.3 & 138.7 & 4.0 \\
\hline 136 & 45.3 & 90.7 & 4.0 \\
\hline 297 & 99 & 236.7 & 4.7 \\
\hline 371 & 123.7 & 247.3 & 3.8 \\
\hline 208 & 69.3 & 138.7 & 4.0 \\
\hline 136 & 45.3 & 90.7 & 4.0 \\
\hline 297 & 99 & 198 & 4 \\
\hline 371 & 123.7 & 247.3 & 3.9 \\
\hline 208 & 69.3 & 138.7 & 4.0 \\
\hline 136 & 45.3 & 90.7 & 4 \\
\hline 279 & 99 & 180 & 3.6 \\
\hline 371 & 123.7 & 247.3 & 3.9 \\
\hline Total & & & 47.9 \\
\hline
\end{tabular}

The table above is a $4 \times 2$ contingency table, hence the degree of freedom.

$(\mathrm{df})=(\mathrm{C}-1)(\mathrm{R}-1)$

$(\mathrm{df})=(4-1)(2-1)$

$\mathrm{df}=3 \times 1=3$

Thus, df $=3$.

The table value of $\mathrm{X}^{2}$ at a significance level of 0.05 and degree of $3=7.815$. The calculated value of $x^{2}=47.9$. Since the calculated value of $\mathrm{X}^{2}$ is greater than the table value of $\mathrm{X}^{2}$, we therefore accept the alternate hypothesis which states that there is a significant relationship between women's involvement in management positions and child care obligations.

\section{Discussion of findings}

From the study carried out on Women in Management Positions and Role Conflict in Wamco Nigeria PLC, we found that:

Women involvement in management positions has contributed greatly in ensuring that they effectively care for their children. This is not in line with Taiwo (2015) that most women who find themselves as managers in organizations tend to have little or no attention for their children. But the it is in line with item 1 in table II as 55.5 percent of the respondents strongly agreed that women's involvement in management positions has enabled them (women) effectively care for their children.

\section{CONCLUSION}

Based on the study conducted on Women in Management Positions and Role Conflict, we conclude that women are involved in managerial positions in organizations, and it has in no way affected their child care obligation in the family.

\section{REFERENCE}

[1] Aguoru G. (2015). Education and Changing Careers of Women in Nigeria. Onitsha: Maduabuchi Printing Press Ltd. (pp. 62-69).

[2] Anyaoha O and Onyema C. (2015). Mothers Work Hours and Childcare Obligation.International Journal of Contemporary Studies. 1(3) (pp.292- 296).

[3] Benson, A. J. (2016) Motherhood and Childcare Obligation.Journa of Gender and Development. 4(4) (pp. 15-20).

[4] Bhafia, C. (1983)The role of women in India. Bombay: Bombay academic press limited. (pp 43-49).

[5] Elvis O .(2016). Emergent and Recurrent Issues Affecting Women in Contemporary Industrial Societies. Journal of Management and Enterprise Development 4(2). (pp.3945).

[6] Ezeigbo J. (2014). The participation of women in labour force. New York: Social Problem academic Press.(pp. 78-87)

[7] Hedges M.(2012). Economic Importance of Women in Labour force. Lagos: Nwokedi Publishers. (pp.35 -42).

[8] Ikenna I and Uwadi C. (2016).Career Women and Family Stability in Nigeria. Journal of Gender and Population Studies. 12(11) (pp.12-20).

[9] Jacobs, J.A. and Gerson, K. (2001). Overworked individuals or overworked families? Explaining trends, world leisure, and family time and occupations review of social economy. (pp.43-49).

[10] Maduba P. (2015). Childcare Obligation of Women and Paid Labour. Journal of Home Economics. 15(15) (pp.281-301). 


\section{International Journal of Engineering Applied Sciences and Technology, 2019 \\ Vol. 4, Issue 8, ISSN No. 2455-2143, Pages 27-32 \\ Published Online December 2019 in IJEAST (http://www.ijeast.com)}

[11] Nwachukwu, C. U (2015) Economic importance of women in Africa. Lagos: Light house academic press.(pp. 21-34).

[12] Obinna, I. (2016)Women and Public Relations in Nigeria, $2^{\text {nd }}$ Edition. Ikeja: Saliu Printing. (pp. 18-23).

[13] Okoronkwo K. (2016). Working mothers and child care obligation in Nigeria. International journal of sociology and anthropology. 9(6) (pp. 28-33).

[14] Oriaku, A. J (2010): The impact of women in management positions on Family Stability. Journal of International Gender Studies.9(9) (pp.34-39).

[15] Ugwulebo. E and Anele K. (2011): The Four M Theory of Women. Owerri: CelBez Publishers. (pp. 34-47).

\section{ACKNOWLEDGEMENTS}

We are greatful to Prof Emma Ugwulebo, Dr. Daniel Nkwocha, Prof. Osita-Njoku Agnes and Prof. Okoroafor C. U for their unreserved assistance during the course of this work. We also acknowledge all the authors that their works were cited in this research. 